\title{
A Liberal Order Beyond Earth? Civil Sphere, "The Culture" and the Future of Liberalism
}

\author{
Werner Binder \\ $\mathrm{PhD}$, Assistant Professor, Department of Sociology, Faculty of Social Studies, \\ Masaryk University, Brno (Czech Republic) \\ Address: Joštova 10, 602 oo Brno, Czech Republic \\ E-mail: werner.binder@muni.cz
}

\begin{abstract}
Starting with George Orwell's liberal problem of meaning, this article investigates liberalism as cultural structure and myth, drawing on the theory of civil sphere by Jeffrey C. Alexander and the science fiction novels of Ian M. Banks. Following Alexander, it is argued that liberal societies are built around a sacred core described by the cultural structures of the civil sphere, which are structures of meaning as well as feeling. Civil discourses and movements in liberal (and not so liberal) societies mobilize powerful symbols of the sacred and profane and are thus able to inspire an almost religious devotion. The article then continues to explore the meaning structure, cultural contradictions and possible future of the liberal order discussing Bank's Culture series. These novels are set in the borderlands of "the Culture", a galactic civilization and liberal utopia. It is precisely this utopian setting, which allows Banks to probe the internal dilemmas of liberalism, for example between pacifism and interventionism, while addressing issues of contemporary relevance, such as the liberal problem of meaning, the allure of authoritarianism or the social status of artificial intelligence. With their literary imagination, science fiction writers construct "a myth of the future" (Banks), which may often reflect the myths of their time, but which can also-as in the case of Banks-reflect on those myths, their implications and contradictions. Finally, the fictional possibilities of social order in science fiction can be a valuable source for our imagination as sociologists contemplating the very possibility of social order.
\end{abstract}

Keywords: cultural sociology, civil sphere, liberalism, authoritarianism, science fiction, "The Culture", Jeffrey C. Alexander, Ian M. Banks

\section{Introduction}

On March 2, 1940, the English (science-fiction) author George Orwell published a remarkable review of Hitler's Mein Kampf. In this short piece for The New English Weekly, Orwell (1940) not only predicted that "the Russo-German Pact represents no more than an alteration of time-table" and that "Russia's turn will come when England is out of the picture", but also offered a Christological reading of Hitler as an iconic collective representation: exhibiting "the face of a man suffering under intolerable wrongs" reproducing "the expression of innumerable pictures of Christ crucified", Hitler stylizes himself as a martyr, victim, and "self-sacrificing hero who fights single-handed against impossible odds". Linking suffering to meaning, Orwell (1940) continues to develop a lucid reading of the contemporary crisis of liberalism: 
[Hitler] has grasped the falsity of the hedonistic attitude to life. Nearly all western thought since the last war, certainly all "progressive" thought, has assumed tacitly that human beings desire nothing beyond ease, security and avoidance of pain. In such a view of life there is no room, for instance, for patriotism and the military virtues. The Socialist who finds his children playing with soldiers is usually upset, but he is never able to think of a substitute for the tin soldiers; tin pacifists somehow won't do. Hitler ... knows that human beings don't only want comfort, safety, short working-hours, hygiene, birth-control and, in general, common sense; they also, at least intermittently, want struggle and self-sacrifice, not to mention drums, flags and loyalty-parades. . . . Fascism and Nazism are psychologically far sounder than any hedonistic conception of life. The same is probably true of Stalin's militarised version of Socialism. All three of the great dictators have enhanced their power by imposing intolerable burdens on their peoples. Whereas Socialism, and even capitalism in a more grudging way, have said to people "I offer you a good time," Hitler has said to them "I offer you struggle, danger and death," and as a result a whole nation flings itself at his feet.

While opposing fascism to capitalism and socialism, Orwell suggests an affinity between "Stalin's militarised version of Socialism" and the former. Thus, the "culture war" described by Orwell is probably better conceived as a conflict between liberalism ("'progressive' thought") in its capitalist and socialist variants, and what can be called "conservative" thought, authoritarianism, or even totalitarianism - the latter being iconically portrayed in Orwell's famous science fiction novel Nineteen Eighty-Four (1949). In his review, Orwell criticizes the flawed anthropology of liberalism which disregards the fact that humans are driven by meaning, and not by pleasure. Orwell concludes with a warning to his readers not to underestimate the "emotional appeal" of fascism, but also offers hope that after "a few years of slaughter and starvation", the star of liberalism might rise again - at least for some time.

I believe that Orwell's brief but lucid analysis not only speaks to his time, but may also be able to shed some light on the contemporary crisis of liberalism which has been challenged by authoritarian movements across the globe, not only in Russia and China, but also in Europe and the United States. In the 1990s, after the "revolutions" of 1989 and the dissolution of the Soviet Union in 1991, many observers predicted a world-wide triumph of liberalism, and with it, the "end of history" (Fukuyama, 1992). Since the 20oos, however, we are witness to a rise of religious fundamentalisms and authoritarian nationalisms which oppose the liberal order as hedonistic and decadent, attacking its apparent lack of meaning. At the other end of the political spectrum, "progressives" have tried to discredit the universalist claims of liberalism, portraying the propagation of liberal values as an ill-disguised form of colonialism or even imperialism.

Nowadays, even self-proclaimed liberals do not shy away from calling liberalism "the light that failed" (Krastev, Holmes, 2020). This failure is not confined to Eastern Europe but also shows in the heartlands of Western liberal democracy. Arguably, liberalism did not live up to its core promise of providing the "Greatest happiness of the greatest number" (Orwell, 1940); now, the promise itself seems compromised. Liberal apologists of 
"the last man" (Fukuyama, 1992) have succumbed to the Nietzschean critics of liberal decadence, of a hedonistic and carefree life. The unfounded belief in the "natural" superiority of the liberal order-often equated with free markets and democratic elections, the latter conceived in the image of the market in which atomized voters "buy the product" that serves their individual interests best-left liberal-democratic societies on shaky foundations. Even worse for a supposedly "progressive" movement, liberalism does not seem to offer a compelling vision of the future any longer.

The following article addresses the foundations of the liberal order and its possible future. My theoretical reference point will be Jeffrey C. Alexander's work on The Civil Sphere (2006). As a cultural sociologist, he is one of a few contemporary authors that recognizes the importance of (collective) emotions and (cultural) meanings for liberaldemocratic societies, since not only fascism, but liberalism also has to rely on its "emotional appeal". According to Alexander, liberalism is not primarily about free markets and democratic elections, but about the way a "common good" is culturally constructed in public discourses and further implemented by social institutions. ${ }^{1}$ In order to thrive, a liberal society not only needs to define a collective interest or "common good" transcending the individual interest of its members, it also needs to create symbols and myths that facilitate a collective emotional attachment. Indeed, Alexander's sociological theory of liberalism can be described as a liberal myth, a utopian ideal whose closest empirical approximations are incomplete and contradictory at best, but an ideal worth fighting for, nevertheless.

The core argument of this article explores liberalism as a literary myth in the Culture series of the science-fiction writer Ian M. Banks. Set in the borderlands of the Culture, a galactic civilization living a liberal utopia bordering on anarchy, these novels address the liberal problem of meaning, the dilemmas of liberalism, as well as the allure of authoritarianism. Under the social and material conditions of the Culture as a post-scarcity society whose miraculous technologies have freed humans (and machines) from almost any conceivable external constraint, the external contradictions of the civil sphere have vanished (along with social divisions based on class, wealth, race, gender, and religion) while its internal contradictions have become more pronounced. With his Culture series, Banks created the myth of a liberal future that not only brings the possibilities, but also the contradictions of liberalism to the fore. The artistic imagination of science-fiction writers is a valuable source for us sociologists by not only illuminating the very possibility of social order, but also in expanding our own sociological imagination in regard to the countless possibilities of (fictive) social orders.

1. It should be noted that Alexander (2006) almost never uses the term "liberalism", preferring "democracy" and "civil society" instead. Nevertheless, the normativity implied in his concept of a "civil sphere" is decidedly liberal and not really compatible with "illiberal" democracies and "reactionary" civil society associations. 


\section{Jeffrey C. Alexander: The Civil Sphere and the Myth of Liberalism}

Liberal thinkers have seldom addressed the liberal problem of meaning so vividly described by Orwell in his review. ${ }^{2}$ Is there something that can hold a liberal society together, aside from hedonistic pleasure-seeking and the pursuit of individual interest? In this regard, Alexander's sociological approach to liberalism is rather exceptional, being informed by the "religious", collective, and cultural understanding of society of the late Émile Durkheim (1995/1912), who himself was an engaged liberal intellectual with socialist leanings (cf. 1969/1898). According to Durkheim, liberal societies are never cut off from the "sacred", which he viewed as the source of all powerful meanings and emotions, but in fact cultivate their own symbolism of the sacred, for example, regarding the sacredness of "the individual" (1969/1898: 21ff.), or "the principle of free discussion" (1995/1912: 215). Likewise, Alexander's cultural sociology (cf. 2003) provides an intellectual testimony to the power of the sacred in modern societies, which is also true for his theory of the "civil sphere" (2006), a sociological reflection on liberalism and democracy in which meanings, emotions, and symbols play a central role.

In contrast to other apologists of liberalism praising the virtues of the free market or functional differentiation in general, Alexander draws his inspiration mainly from civil struggles within Western democracies, (e.g., the civil rights movement) and outside of them (e.g., the "revolutions" of 1989), which led to the rise of "civil society" as a key concept in public as well as academic discourses. For Alexander (2006), it is precisely the existence of a civil society, or the autonomy of a "civil sphere" respectively, that is the hallmark of a liberal-democratic society. Civil society and its discourse embody the orientation towards a common good deemed indispensable for the proper functioning of a liberal order. Civil discourses and movements mobilize powerful symbols of the sacred (and profane) and weave modern myths about salvation (and damnation), thus inspiring devotion akin to religious movements. Civil actors often engage in righteous acts, making sacrifices and taking risks on behalf of others (Tognato et al., 2020). Far from being decadent, hedonistic and shallow, flourishing civil societies are rooted in deep cultural structures. The "civil sphere" at the center of any liberal-democratic society is foremost a "structure of feeling" - shaped by powerful cultural binaries and narratives which link actors, relations, and institutions to the sacred and its profane counterpart-with the function to promote solidarity among its members. ${ }^{3}$

Despite its mythical underpinnings and utopian aspirations, every civil sphere is a "real" instantiation and concrete manifestation of ideal liberal principles under specific historical circumstances, which inevitably leads to shortcomings and contradictions. In its day-to-day business, a civil sphere has to rely on specialized institutions, such as communicative institutions like the press and mass media on the one hand, and regulative

2. John Rawls (1999), for example, simply assumes that his version of utilitarianism is able to provide the basis for a liberal order which can be agreed upon between rational individuals (cf. Alexander, 2006: 13-15).

3. Here, the theory of the civil sphere is clearly indebted to Parsons and his conception of "societal community", a societal sub-system that facilitates the integration of society via the inclusion of its members as citizens. 
institutions like political offices, elections, and the law on the other hand. Often, these institutions operate under non-civil pressures (e.g., to make profit or secure power), which may threaten the autonomy of the civil sphere. Furthermore, there is an inevitable clash between the civil sphere and other spheres (such as the market, race, or religion), which can lead to civil intrusions and backlash movements (Alexander, 2019). While some contradictions arise due to external constraints, some seem to derive from the internal logic of civil discourses themselves because their universal aspirations are always bound to particular communities, and in promoting inclusiveness, they unavoidably produce exclusion.

Alexander's theory of the civil sphere has to be viewed as part of his broader cultural sociology with the self-proclaimed task "to bring the unconscious cultural structures that regulate society into the light of the mind" in order "to reveal to men and women the myths that think them so that they can make new myths in turn" (2003: 3f.). In some sense, Alexander is not just an analyst of cultural structures shaping contemporary political discourses but he himself became the creator of a cultural sociological myth of liberalism whose aim is to empower liberal activists world-wide. It is not only sociological theory, but also literature that can become part of the mythical structure of society, which accounts for Alexander's recurring interest in literature in The Civil Sphere (2006), not primarily as a mirror of society, but as a cultural force challenging prevailing myths and creating new ones. According to the author Banks, science fiction can be described as an attempt "to construct a myth of the future" (Branscobe, Banks, 2007). Nevertheless, science fiction as a genre, with the possible exception of dystopian works like Orwell's Nineteen Eighty-Four, is often dismissed as adolescent wish-fulfillment and not regarded as literature in the proper sense. Furthermore, much of science fiction, once it was no longer just about adventure stories in space, has been overly focused on technology and the "hard sciences", which unconsciously tended to reproduce the "myths" and ideological presuppositions of their time. In contrast, with his Culture series, Banks created an artificial myth that allows us to reflect on the myths of contemporary society, exploring their implications and contradictions, and may also help us to shape its future.

\section{Iain M. Banks: The Culture as Myth of a Liberal Future}

Iain Menzies Banks was a Scottish novelist (1954-2013) who wrote mainstream fiction under the name of Iain Banks, and science fiction as Iain M. Banks. Already in the 197os, he started to work on three science fiction novels, two of which were later published as part of his Culture series, but he made his debut with Wasp Factory (1984) and other mainstream fiction novels. It was only in 1987 , after he had established his reputation as a "serious" writer, that he was able to publish his first science fiction novel Consider Phlebas, the first of nine Culture novels (plus one novella and a short story). As a novelist, Banks not only won critical acclaim-he was listed by The Times in 2008 as one of the "50 greatest British writers since 1945" (The Times, 2008) - but also gained considerable scholarly attention (e.g., Colebrook, Cox, 2013; Kincaid, 2018). In the following, I will 
limit my discussion of liberalism in Banks' work to his Culture series, although many of its themes and topics appear in his mainstream novels as well, and vice versa.

If there is something that literary critics and scholars can agree upon, it is the fact that Banks' writing is deeply political, his Culture novels in particular. Banks' political views might be more influential than many people think, ${ }^{4}$ but they do not fit easily into established categories, and the same can be said of the politics of the Culture. Banks' science fiction utopia has been rightly called liberal, communist, and anarchist, but also wrongly described as "monolithic totalitarianism". ${ }^{5}$ While such characterizations often reflect the political bias of the reader, I believe that the Culture has to be understood in its own terms-or at least in those of Banks.

Critics seem to have a strong inclination to read fantasy novels such as Tolkien's Lord of the Rings or science fiction novels like the Culture series as historical and political allegories. Orwell's Animal Farm and Nineteen Eighty-Four have both been read allegorically, with diverging plausibility. ${ }^{6}$ Similarly, many critics and scholars have read Banks' Culture novels - at least in part—as historical-political allegories. Patricia Kerslake, for example, identified the Culture with the liberal West, arguing that "the warlike Idirans violently oppose the Culture, a position highly reminiscent of the Soviet Union and the United States during the Cold War" (2007: 176; also Nussbaum, 2018). Others have likened Banks' Culture to the post-Stalinist Soviet Union (Mendlesohn, 2005: 122); more to the point, his Scottish colleague Ken MacLeod (2003) argued that Consider Phlebas (1987) has been influenced by the Soviet invasion of Afghanistan-favoring the Communist infidels over religious fanatics (and thus a critique of Frank Herbert's Dune). Others have noted influences and parallels to the Gulf War and the Iraq War (Duggan 2007); Look to Windward (2000), which is dedicated to "the Gulf War Veterans", could even be read as a prophetic anticipation of $9 / 11$ (Jones, 2001).

While historical experiences have certainly informed Banks' Culture series, an allegorical reading does not do it justice. The Culture series does not just offer a mirror image of our world and its history but constitutes a universe of its own. In this regard, Banks' Culture series is on par with the world-building of J. R. R. Tolkien in The Lord of the Rings, in whose foreword to the second edition we find the following rebuttal of an allegorical reading of his work: “. . . I cordially dislike allegory in all its manifestations, and always have done so since I grew old and wary enough to detect its presence. I much

4. The richest man on the planet, Jeff Bezos, described Banks' Culture series as "a huge personal favorite" (February 21, 2018, on Twitter), while the current number two, Elon Musk, called himself "a utopian anarchist of the kind best described by Iain Banks" (June 17, 2018, on Twitter), and even named two SpaceX drones after spaceships from the Culture series; cf. Stubby the Rocket (2015).

5. Stuart Kelly, thus demonstrating his own flawed understanding of Banks (2018).

6. Animal Farm can and indeed should be read as a parable of the Russian Revolution; the use of animals as protagonists is a literary convention that clearly signifies the genre of the fable which can be considered an invitation for allegorical readings. An allegorical reading, however, is not warranted in the case of Nineteen Eighty-Four, which some (conservative) critics have considered as a political commentary on English postwar socialism (btw., like "The Scouring of the Shire", the last chapter of Lord of the Rings). While inspired by historical facts, the totalitarian dystopia of Nineteen Eighty-Four has to be regarded as a literary ideal-typical construction in its own right-not unlike the Culture novels of Banks. 
prefer history - true or feigned - with its varied applicability to the thought and experience of readers. I think that many confuse applicability with allegory, but the one resides in the freedom of the reader, and the other in the purposed domination of the author" (1995/1965: xvii).

The same argument can be applied to Banks' Culture series, which revolves around the liberal struggle of freedom against domination. While some of its themes echo the dark sides of human history such as slavery, exploitation, and colonialism, they primarily have to be read as part of the universe constructed by Banks. Nevertheless, his writing can be applied to historical events, partly because its abstractions and idealizations are rooted in historical experience. For example, the resemblance of the plot of Look to Windward (2000), in which a suicide bomber attempts to destroy a Culture orbital, to 9/11 and the American-led War on Terror is not merely coincidental (as falsely suggested by Kincaid, 2018); the timing might be, but the issues that are addressed are not. The problem of terrorism and the dilemmas of the liberal response are structurally implied in the conception of technologically advanced societies and the logic of liberalism. Otherwise, it would have been impossible for a sociological thinker like Niklas Luhmann (2008/1993) to discuss what later would be called the "ticking-bomb scenario". Like sociological thinking, literature allows for abstractions and idealizations that can be applied to historical and contemporary events.

So what is the Culture if not simply a historical or political analogy? In an interview with Tim Metcalfe in 1989, Banks explained the rationale behind the creation of the Culture as follows:

I wanted to say, "Look, there is a possibility of something really good in the future. Here's a genuine, humanist, non-superstitious, nonreligious, functioning utopia where absolutely no-one is exploited; where they don't have money, where they don't have laws to speak of, my idea of a perfect society-and it's obviously not capitalist-but it's so communist it's beyond anything in a way. Something like the Culture could just about evolve from capitalism" (quoted in Martingale, 2013: 441).

Like Orwell, who called himself a socialist but was opposed to Stalin, Banks transcends established political binaries. His Culture series is neither an apology of 2oth century capitalism or communism but offers an idealized image of a liberal society centered on personal freedom and non-exploitation which is projected into the far future. Like Orwell in his review (and in Nineteen Eighty-Four, a dystopian image of an illiberal totalitarian society), Banks is primarily interested in the contrast between liberal and authoritarian societies. In his first Culture novel, Consider Phlebas (1987), the authoritarian faction, the Idirans, are religiously motivated; in subsequent novels, we also find authoritarian societies based on capitalism or caste systems. For Banks, it seems, all liberal societies are alike, converging on an ideal that looks like the Culture, while each authoritarian society is repressive and exploitative in its own way.

In comparison to Orwell's totalitarian dystopia Nineteen Eighty-Four (1949), Banks' construction of a liberal utopia faces unique narrative challenges. To tell a captivating 
story that ultimately matters in a utopian setting is incredibly difficult, so the plot of a Culture novel is usually situated at the fringes of the Culture; while it is certainly possible to tell a story entirely within the Culture, it would cease to be a story about the Culture (cf. Jacobs, 2009). For the same reason, Culture novels are often narrated from the viewpoint of outsiders. An example is Horza in Consider Phlebas (1987), who detests the Culture for being run by machines. In contrast to "authoritarian fiction" (Suleiman, 1983), in which outsider protagonists are usually converted into true believers, Banks' "liberal fiction" refrains from such rhetoric devices, ${ }^{7}$ blurring the boundaries and empowering the reader instead. While the latter learns to sympathize with Horza, the main protagonist, who finds himself collaborating with machines and Culture citizens, is finally betrayed by his Idiran allies. Nevertheless, at no point in the story does Horza disavow his beliefs. Instead, it is the Culture citizen Balveda who questions her involvement in the "just" war against the Idirans in the epilogue of the book. Although consistently portrayed as a liberal utopia, the narrative progression in the novels tends to highlight its inner contradictions of the Culture.

It is still possible to read the Culture novels as a political Bildungsroman, as we will see later, its most important lesson being the "diabolic" nature of politic: a recognition of the fact that bad things can come from good intentions (cf. Weber, 1949). Contrary to the assertions of critics (e.g., Kincaid, 2018), Banks never abandoned the Culture as a liberal utopia, but purposively choose to play the devil's advocate: "Right from the start I was trying not to proselytise. The Culture's not perfect, but it's as close to perfection as you can get with anything remotely human (and still probably far better than we can expect)" (Branscobe, Banks, 2007). It is this refusal to proselytize which allows Banks to probe the inner contradictions of liberalism in his Culture novels. They do not result from "imperfections" or "bad" intentions on the side of the Culture, but from the paradoxes built into the very foundation of a liberal order. Banks pushes the utopian genre to its limits, relentlessly exploring the contradictions and tensions of liberalism. This excerpt from a eulogy for Banks sums it up perfectly: "Because the Culture is an abstracted, idealized version of our own liberal societies, extrapolated out into a situation in which all problems of material scarcity have been solved through automation and machine intelligence on a scale of which we can only begin to dream, the dilemmas that the Culture faces are our dilemmas, sketched on a fabulous canvas that allows Banks to explore them in ideal-typical purity" (Jackson, 2013).

Banks' Culture novels are not historical-political allegories, but literary thought experiments which dissect contemporary myths of liberalism, probe their far-reaching implications, and offer their own liberal myth of the future. In order to analyze the meaning structure and dilemmas of liberalism in Banks' Culture series, we first need to investigate his world-building informed by his own theoretical considerations, which allows him to construct the Culture as a plausible, although fictional, embodiment of the liberal order.

7. With the possible exception of Gurgeh in The Player of Games (1989), a dissatisfied Culture citizen who comes to terms with his own society at the end of the story after beating the authoritarian Azad at their own game. 


\section{The Nomos beyond Earth: The Culture as a Spacefaring and Space-Dwelling Civilization}

As the name suggests, science fiction as a literary genre has always had an interest in scientific theory, especially pertaining to natural sciences such as physics. The proper use of scientific theory is still regarded in fan circles as the distinguishing feature between "hard" and "soft" science fiction, despite the fact that the binary was originally created to single out science fiction which had a focus on human "soft" sciences, such as psychology, anthropology, and sociology (cf. Prucher, 2007: 191). According to both criteria, Banks' Culture series qualifies as "soft" science fiction. Banks' "liberal" use of science and technology does not confine itself to known or even remotely plausible science, featuring "impossible" technologies such as faster-than-light travel (and faster-than-light communications, crucial for a galaxy-spanning civil sphere), and a fantastic speculative cosmology (including multiple dimensions and universes as well as spaces between and beyond them). At the same time, Banks devoted much of his effort to theorize the mental, social, and cultural aspects of space-faring civilizations. In order to outline the social and political theory implied in the Culture novels, we will have to discuss the role of (outer) space in shaping the form of life and the civil sphere of the Culture.

Even cultural sociologists who emphasize the autonomy and internal logic of culture and society have to concede, at some point, that real societies are partially shaped by their history and external circumstances, with civil society being no exception. Talking about its contradictions, Alexander comments in a brief section on "The Geography of Civil Society" on the territorial aspect of the civil sphere, which "is not just some place, or any place, a "center", a place that is different from places outside this territory" (2006: 196). Even liberal-democratic societies with universal aspirations have their homeland and their own national myths of origin. The spatial instantiation and territorialization of the civil sphere gives birth to a multitude of more-or-less civil societies with their own laws and conceptions of the sacred.

The thought that political order is always also a spatial order originates in the works of Carl Schmitt. In Land and Sea (1997/1942), Schmitt explores the cultural-political differences between seafaring and land-dwelling civilizations, a dichotomy superseded by the discovery and conquest of the third dimension with airplanes. He develops this conception of a spatial-political order further in the The Nomos of the Earth-the Greek word nomos meaning "territory" as well as "law" - investigating the changing spatial-political orders in history: "Development of modem technology has robbed the sea of its elemental character. A new, third dimension-airspace-has become the force-field of human power and activity. Today, many believe that the whole world, our planet, is now only a landing field or an airport, a storehouse of raw materials, and a mother ship for travel in outer space. That certainly is fantastic. But it demonstrates the power with which the question of a new nomos of the earth is being posed" (2003/1950: 354).

According to Schmitt, a new nomos of the earth, reflecting the impact of modern technology on the spatial order, has yet to arrive. While Schmitt's last "fantastic" example, 
that of spaceship Earth, touches upon the possibility of a nomos beyond the earth, he treats it as a mere extension of the airspace. Following in the footsteps of Schmitt, other authors have shown how the old nomos of earth, characterized by territorialization, is challenged by the compression of space via technology and the transgression of territorial boundaries in an age of globalization and climate change. Peter Sloterdijk (2015) showed how the imagination of the earth has been transformed from an open territory into an ever-closer globe, while Bruno Latour (2017) has argued that the climate catastrophe of the Anthropocene led to the emergence of a new political conflict between the humans and their successors, the "earthbound". Latour devotes a lot of attention to a paragraph towards the end of Schmitt's foreword to The Nomos of the Earth which is also of eminent interest for us:

The traditional Eurocentric order of international law is foundering today, as is the old nomos of the earth. This order arose from a legendary and unforeseen discovery of a new world, from an unrepeatable historical event. Only in fantastic parallels can one imagine a modern recurrence, such as men on their way to the moon discovering a new and hitherto unknown planet that could be exploited freely and utilized effectively to relieve their struggles on earth. The question of a new nomos of the earth will not be answered with such fantasies, any more than it will be with further scientific discoveries. Human thinking again must be directed to the elemental orders of its terrestrial being here and now. We seek to understand the normative order of the earth. (Schmitt, 2003/1950: 39)

Schmitt-like Latour-stresses the inescapable character of a terrestrial spatial-political order. For Schmitt, the possibility of extraterrestrial colonization is no more than a fantasy that entails the mere extension of the old nomos of the Earth into space. Most of modern science fiction, indulging in such "fantasies", seems to support Schmitt's thesis by combing futuristic technologies with star-spanning empires and other neo-feudal elements (Asimov, Herbert, etc.). There are a few exceptions, notably Banks, who posed the question of a nomos beyond Earth, perhaps in the most radical way. According to Banks, the vastness and hostility of outer space leads to very different conceptions of the spatialpolitical order compared to the ones we know from human history. Humanity, once it becomes a spacefaring and space-dwelling civilization, will eventually move beyond the nomos of the earth. The Culture exemplifies one possibility for such a nomos of space, as explored by Banks in his novels.

The rationale behind Banks' world building and his conception of the Culture finds its clearest expression in a short online commentary from 1994 titled "A Few Notes on the Culture" (Banks, 1994). Here, Basks argues that spacefaring and space-dwelling societies will develop social and political orders that are radically different from seafaring, land-dwelling, or even planet-bound civilizations due to the constraints and affordances of their environment: "The Culture, in its history and its on-going form, is an expression of the idea that the nature of space itself determines the type of civilisations which will thrive there. ... Essentially, the contention is that our currently dominant power systems 
cannot long survive in space; beyond a certain technological level a degree of anarchy is arguably inevitable and anyway preferable" (Ibid.).

According to Banks, living in space entails self-sufficiency and mobility, which makes it almost impossible to control large territories or prevent dissenting groups from breaking off. At the same time, the vulnerability of space habitats and ships reinforces the dependence of the crew on each other and their technology, which facilitates a strong cohesion within groups: "The theory here is that the property and social relations of longterm space-dwelling (especially over generations) would be of a fundamentally different type compared to the norm on a planet; the mutuality of dependence involved in an environment which is inherently hostile would necessitate an internal social coherence which would contrast with the external casualness typifying the relations between such ships/habitats" (Ibid.).

Consequently, the social structure within autonomous groups in space and the social relations between such groups will diverge drastically, resulting in what Banks dubs "socialism within, anarchy without". The Culture is an acephal society, without a center or even a territory, composed of autonomous units each representing the Culture as a whole. Like the monads of Leibniz, each unit mirrors the Culture in its own way, but without a central monad, which is Leibniz's God. The members of separate groups, usually sharing the same space-habitat or spaceship, can move freely between these groups as it suits their individual needs and political views, or even defect from the Culture altogether. What holds the Culture together is neither domination nor territory, but solidarity facilitated by a shared structure of meaning.

According to Banks, the nomos of space, the social-spatial order of a spacefaring and space-dwelling civilization, views planets and stars mainly as sources of material and energy to be exploited for the construction and maintenance of ships and artificial habitats, a more efficient and thus superior mode of existence than planet-dwelling, according to the Culture. This reductionist view of celestial bodies is counteracted by the Culture's appreciation of complexity, biological and cultural diversity in particular. "Terraforming" is not only rejected as inefficient but also as "ecologically unsound" (Ibid.). Planets are treated as nature preserves, something to be visited and studied, not to be colonized and exploited. The sheer abundance of material and energy in the galaxy renders the act of "land-appropriation" (Schmitt, 2003/1950: 8off.) superfluous, and the control of vast territories unnecessary. ${ }^{8}$

The vast majority of the citizens of the Culture lives on artificial habitats and ships. The spatial order of the Culture might not have a center in the political sense, but it is divided in multiple centers and peripheries in a social sense, mirroring the urban-rural divide. As The Player of Games informs us, "the Culture's real cities were its great ships,

8. It should be noted that Banks mentions the scarcity of resources and energy as a rationale behind the creation of digital afterlives by many galactic civilizations in Surface Detail (2010). However, these limitations seem not to apply to the Culture, maybe for technological reasons (the Culture is able to generate energy from the fabric of the multiverse itself) or cultural reasons (despite de-facto immortality, either as an organism or in digital form, voluntary death is a common practice for the biological members of the Culture). 
the General Systems Vehicles", sometimes populated by billions of people, "Orbitals were its rustic hinterland, where people liked to spread them out with plenty of elbow room" (1988: 49). Even the huge orbitals, with a surface area of multiple Earths, are mobile in principle, which is not only important in times of armed conflict but gives the entire Culture a nomadic character. In contrast to other galactic civilizations, which often revere their home planet (or other celestial bodies) as sacred, the Culture-a melting pot of several humanoid species - has no home planet and is not attached to any particular place in the galaxy (although some of its members might be).

The nomos of space as imagined by Banks highlights some peculiar limitations of the terrestrial civil sphere. While the existence of several territorially bound societies and states allows for an exit option in principle, there is no such option for the whole Earth as a globe. We are earthbound, as Latour says, and, as Schmitt attests, all land on the planet has been appropriated and divided politically. People can flee certain territories but there is no escape from the logic of territorialization. In contrast, the abundance of resources and the vastness of space always allows for exit options encouraging people to form likeminded communities. While the Culture shares a common structure of meaning, its civil sphere is not policed centrally and becomes fuzzy at the edges. Not only is defection a possibility, but individual groups may also slowly gravitate away from what most Culture citizens deem appropriate, though only in rare cases does this warrant policing or even military action on part of the Culture.

\section{The Culture as a Civil Sphere and its Citizens}

While its individual constituents may be internally socialist and externally anarchic, the Culture as a whole can be described as a civil sphere based on liberal principles, expression of freedom and absence of exploitation in particular. Nevertheless, this cultural structure is also applied to other societies since its principles are regarded to be universal. While Banks himself may have tried his best not to proselytize in his novels, the Culture itself is portrayed as driven by a missionary zeal to spread its liberal values throughout the galaxy. It engages in a civilizing mission, which is precisely the opposite of Star Trek's "prime directive" (based on the principle of non-interference), as many commentators have noted. It is the fundamental conflict between liberal and authoritarian values and the often-unintended consequences of liberal interventions which drives the plot in all Culture novels. Before we address the problem of liberal interventionism, it is necessary to provide a brief outline of the Culture as a civil sphere.

According to Alexander (2006), the "inclusion" or "incorporation" of the members of a society as "citizens" is one of the most important functions of the civil sphere. Civil spheres have to balance "solidarity" and "difference", social cohesion and cultural diversity, the requirements of social order with calls for individual autonomy. Alexander suggests there is a tendency in modern liberal societies to shift from assimilation to a multi-cultural mode of incorporation (2006: 395-457), which reflects these premises. The liberal order stands and falls with the assumption that achieving this balance is not a 
zero-sum game: we do not lose in solidarity what we gain in recognition of difference; cultural diversity is not a threat to social cohesion in itself; and increasing demands for individual autonomy can not only be integrated into the social order but can even form the basis of such an order.

Being a fusion of several humanoid species, it can be argued that the Culture has inclusiveness and diversity in its DNA. Due to the mastery of genetics and bioengineering, the Culture effectively has erased the boundaries of gender and race, either of which can be chosen and altered by its members at will. Gender chauvinism and racism are primarily encountered in other more authoritarian societies, such as the empire of Azad in which a third gender ruthlessly dominates and exploits its male and female counterparts (Banks, 1989). Along with liberal freedoms comes a set of normative expectations, too: not only is a sex-change easy, one is also expected to have at least one in their lifetime; one is also expected to give birth to a child, which is only possible as a female. The male protagonist of The Player of Games, Gurgeh, is treated with suspicion for sticking to his birth sex and for not trying out homosexual relationships (28). While these normative expectations are not strongly enforced, they demonstrate that the lifestyle of the Culture not only promotes diversity on a societal level but also in its members, who are constantly encouraged by their fellow citizens to have diverse experiences and live life to the fullest.

It can be argued that a specific genetic and bodily makeup is crucial for being a citizen of the Culture. Endowed with above-average intelligence, powerful drug-glands, the ability for self-repair, the capacity to change their sex and other aspects of their body at will (although this takes time), and practical immortality, the humanoids of the Culture are superhuman entities. Banks notices that with such a biological setup it is potentially easy to subjugate populations of less developed populations, which is why the Culture reserves the right to withdraw the birthright of a Culture citizen, if there is a danger of illiberal abuse (Banks, 1994). Such a bio-technical devolution is the equivalent to the withdrawal of citizenship. On the flip side, humanoids and other beings that decide to become citizens of the Culture are entitled to a biological upgrade. The biological setup of Culture citizens, especially their improved sexual capacities and drug glands, make them the object of admiration of other species, even though they may otherwise despise the Culture.

Not all citizens of the Culture are biological, though. While artificial intelligence of sub-human, human, or even superhuman levels exists in all developed civilizations of the Culture universe, the unique thing about the Culture is that it grants all "sentient machines", as it prefers to call AIs, full citizenship status. The liberal principles of freedom and non-exploitation also apply to the sentient machines, which Banks renders plausible by the following argument (Ibid.):

No machine is exploited, either; the idea here being that any job can be automated in such a way as to ensure that it can be done by a machine well below the level of potential consciousness ... Where intelligent supervision of a manufacturing or maintenance operation is required, the intellectual challenge involved (and the relative lightness of the effort required) would make such supervision rewarding and enjoyable, whether for human or machine. 
In other words, there is no exploitation of the sentient labor force in the Culture because every work requiring a certain level of sentience is intrinsically "rewarding and enjoyable" and thus "indistinguishable from play", if not by all, at least by some Culture citizens. Given the trillions of inhabitants of the Culture, it is just a matter of logistics to find the right person, regardless of whether it is humanoid or a human-level "drone", for a job that it will find "rewarding and enjoyable", a task that the artificial-super-intelligences of the Culture, the god-like "minds", seem to find "rewarding and enjoyable". The minds not only operate the orbitals and spaceships of the Culture; they can also be described as its de-facto rulers. Horza, the main protagonist of Consider Phlebas, despises the Culture precisely for this reason: "I don't care how self-righteous the Culture feels, or how many people the Idirans kill. They're on the side of life-boring, old-fashioned, biological life; smelly, fallible and short-sighted, God knows, but real life. You're ruled by your machines. You're an evolutionary dead end" (1987: 29).

It is the luddite fear and hatred of machines that replaces racism in the setting of the Culture. While many galactic civilizations are racial supremacists regarding their own species, what unites them against the Culture is their belief that machines should stay in their place and do as they are told. Thus, Banks not only offers a reflection on racism and inclusion in contemporary societies, but also a controversial contribution to ongoing debates on artificial intelligence which tend to portray autonomous AI as an existential threat. On January 12, 2015, Nick Bostrom, Stephen Hawking, Elon Musk, and others signed an open letter acknowledging the tremendous potential of artificial intelligence, but also cautioned that "our AI systems must do what we want them to do" (Future of Life Institute, 2020). This eerily echoes the conservative criticism of liberalism, which doubts the capacity of human beings to make free choices for their own good and the good of others. Such reasoning is an anathema for the Culture, which advocates freedom for all sentient matter.

Nowadays, many liberals are willing to extend rights to other living beings, but this usually stops at machines which need to be controlled. Those authors that otherwise reject Hobbes' dark anthropology of "homo homini lupus est" nonetheless subscribe to the statement "machina homini lupus est". Banks' literary thought experiment radicalizes the presuppositions of liberalism and envisions a solidarity between biological and mechanical life: why shouldn't it be possible for machines created in a liberal society to share the reasoning, emotions, and idealism of their fellow humanoid citizens? Banks questions the human impulse to dominate machines and appeals to our faith in liberalism, arguing that its principles will also appeal to sentient machines. It should be noted that the decision to empower and grant autonomy as well as citizenship to their machines is portrayed as the single most important reason behind the Culture becoming a superpower. This mirrors liberal arguments throughout the ages that the inclusion and empowerment of the masses provides a distinctive advantage to liberal societies.

In the post-scarcity society of the Culture, there is little room for tensions and clashes between the civil sphere and other spheres. The economic sphere of the market has been replaced by economic planning and an economy of gift-giving and voluntary work, which 
is basically an extension of the civil logic to the material realm. Similarly, the Culture does not exist as a state, only as groups of individuals, each and no one representing the Culture as such. Culture citizens act according to their own reasoning and have to reach a consensus every time anew in what could be called political or legal matters. Other spheres mentioned by Alexander (2006), for example religion, race, and gender, play no role at all as these distinctions no longer serve as bases for social divisions.

Even the civil sphere of the Culture is only weakly institutionalized. There are communicative institutions, such as entertainment media and news services, as well as regulative institutions such as political offices and popular votes, but they operate on an informal basis and not as formal organizations. What is most striking is probably the absence of law. The Culture has no laws, only social conventions whose enforcement relies on individual participation and public consensus every time. "The court of informed public opinion" (Banks, 2010: 155) is literally the highest authority. On contested matters, conflicts are resolved through voting. The principle of "one man, one vote" does not hold: greater weight is given to votes on the basis of sentience (which privileges the Culture minds) and concerned-ness (e.g., in human matters, human votes are given a larger weight). Most voting takes place at the local level, among the inhabitants of a specific community, ship or orbital; in the rare case of matters concerning the Culture as a whole, such as the declaration of the Idiran-Culture war, there is civilization-wide voting. While the outcome of the voting determines the collective course of action, it is individually non-binding. There is always the option to leave the community and even the Culture as such, which, for example, resulted in the split-off of the pacifist faction in the IdiranCulture War.

\section{The Liberal Problem of Meaning}

As a post-scarcity society, the Culture has overcome the Hobbesian state of nature where life was "nasty, brutish and short". All material needs of Culture citizens are effortlessly satisfied, the labor they provide is "indistinguishable from play, or a hobby", and they enjoy extended lifespans or even immortality. At the same time, the humanoids that created the Culture are no longer really needed: they "are unnecessary for the running of the starships, and have a status somewhere between passengers, pets and parasites" (Banks, 1994). In a society in which "the greatest happiness of all" has become a real possibility, the liberal problem of meaning addressed by Orwell moves to the foreground, on a personal as well as on a societal level. The following passage from Nietzsche's Zarathustra offers a seemingly accurate portrayal of life in the Culture (2006: 10):

"What is love? What is creation? What is longing? What is a star?"-thus asks the last human being, blinking. Then the earth has become small, and on it hops the last human being, who makes everything small. His kind is ineradicable, like the flea beetle; the last human being lives longest. "We invented happiness"-say the last human beings, blinking. They abandoned the regions where it was hard to live: for one needs warmth. ... A bit of poison once in a while; that makes for pleasant 
dreams. And much poison at the end, for a pleasant death. One still works, for work is a form of entertainment. But one sees to it that the entertainment is not a strain. One no longer becomes poor and rich: both are too burdensome. Who wants to rule anymore? Who wants to obey anymore? Both are too burdensome.

While Culture citizens are biologically superhumans, they live the life of Nietzsche's last man, as fleas in the fur of mighty spaceships and orbitals, tailored to and caring for their needs, enjoying drugs, entertainment, and a life without burden in an egalitarian society. It seems that the Culture as a society has not much to offer to its citizens in terms of meaning. In the "Notes on the Culture", Banks states that "Philosophically, the Culture accepts, generally, that questions such as "What is the meaning of life?" are themselves meaningless" (Banks, 1994). In the end, the quest for meaning is delegated to the individual: "we make our own meanings, whether we like it or not".

The liberal problem of meaning as a personal issue is best reflected in The Player of Games (1989). The novel starts with Gurgeh, a dedicated player of all kinds of games, talking about what could be called his midlife-crisis with a befriended drone: "Everything seems gray at the moment, Chamlis. Sometimes I start to think I'm repeating myself, that even new games are old ones in disguise, and nothing's worth playing for anyway" (22).

The problem of meaning contemplated in the Culture novels is not something completely foreign to members of today's affluent societies but is exacerbated by the long lifespan of Culture citizens and the fact that even extravagant material desires can be easily satisfied. What is the point of betting, Gurgeh asks, if you can have anything? In contrast, games outside of the Culture are often portrayed as barbaric and risky. An example is "Damage" (Banks, 1987), where players not only bet fortunes but also have to bring real "lives" to the table, that is, sentient creatures which are willing to die in their place; in the game of "Azad" (1989), which determines one's place in an authoritarian society, bets often involve the amputation of limbs. The authoritarian societies portrayed in the Culture series are based on suffering and sacrifice, which Banks condemns but also recognizes as powerful sources of meaning. Chamlis, the drone conversing with Gurgeh, points out that his desires cannot be fulfilled within the liberalism of the Culture: "We're well free of that. You want something you can't have, Gurgeh. You enjoy your life in the Culture, but it can't provide you with sufficient threats; the true gambler needs the excitement of potential loss, even ruin, to feel wholly alive" (22).

In the course of the novel, the hero embarks on a quest to beat the authoritarian Azad at their own game, played with high stakes, while simultaneously compensating for the lack of meaning in his life and advancing the goals of the Culture. Despite the entertainment and distractions that perfect virtual environments can offer, there is a longing for the "real" in the Culture, even if it entails suffering or the risk of death. In Consider Phlebas, we meet the Culture citizen Fal who has a passion for unsupervised hiking trips, the last of which ended with her lying "in the snow with a shattered leg for a day and a night before a search party had discovered her" (1987: 88). In Look to Windward (2000), we 
see Culture citizens engaging in various dangerous activities and sports, not only risking their lives but doing so without recent digital backup. ${ }^{9}$

At times, Banks seems to offer a critical portrayal of Culture citizens as easily bored thrill-seekers, which are willing to throw away their lives for a kick because nothing else matters. Nevertheless, without any doubt, he would have preferred to live in an affluent society where people can freely risk and even end their lives. We may not do without "tin soldiers" (cf. Orwell, 1940), but replacing involuntary suffering and war with dangerous sports and war games is definitely an improvement from a liberal perspective. Despite their otherwise comfortable lives, citizens of the Culture are not shallow hedonists, but value hardships, risks, and even sacrifices as sources of meaning for their personal life, as long as they are freely chosen and self-imposed. Other civilizations may regard these practices as the pinnacle of decadence, but the Culture views them as the embodiment of its sacred principles.

The liberal problem of meaning has not only a private and personal but also a public and political dimension. According to Banks (1994), the education of Culture citizens raises awareness of the fact that its liberal achievements should not be taken for granted:

Part of their education, both initially and continually, comprises the understanding that beings less fortunate-though no less intellectually or morally worthy-than themselves have suffered and, elsewhere, are still suffering. For the Culture to continue without terminal decadence, the point needs to be made, regularly, that its easy hedonism is not some ground-state of nature, but something desirable, assiduously worked for in the past, not necessarily easily attained, and requiring appreciation and maintenance both in the present and the future.

The seemingly care-free life of Culture citizens is based on the work of previous generations and requires the ongoing care of the Culture minds and all other Culture citizens, which at least have to maintain their civility in everyday life. In order to endow their liberal utopia with strong meanings, the Culture relies on a liberal/authoritarian binary, on the remembrance of barbarisms in its own past and the recognition of the suffering of others in the present. For Alan Jacobs (2009: 49) — recalling the suffering of the innocent child in Dostoevsky's Brothers Karamazov — the fact that Culture citizens seem to rely on the suffering of others to experience their lives as meaningful casts a dark shadow on the Culture. From a cultural sociological perspective, especially one informed by Durkheim's theory of the sacred, this seems rather unavoidable: meanings arise only through distinctions, and strong meanings emerge from emotionally charged oppositions. The strong meaning structure of the Culture, its sacred core, is the driving force behind its missionary zeal, its open and hidden efforts to undermine authoritarian rule throughout the galaxy, and to liberate those suffering from it.

9. As we learn in Surface Detail (2010), the technology of "backing-up" the mind-state of a person does not reverse death: if I die, a digital copy of a previous mind state of mine will continue to exist, but is that copy actually me, whose stream of consciousness is upended by death? 
The war of the Culture against the Idirans, which is the immediate context of Consider Phlebas (Banks, 1987) with a fallout which runs like a thread throughout the whole series, is the paradigmatic exemplification of the Culture's militant belief in the moral superiority of liberalism. While the authoritarian Idirans are no direct threat for the Culture, noninterference would have meant "the loss of its purpose and that clarity of conscience; the destruction of its spirit; the surrender of its soul" (452). Banks makes it clear that it was not the Idirans that had to fight this war, but the Culture, which "knew from the start" that this was "a religious war in the fullest sense" (451). Nevertheless, there are those who doubt, even within the Culture, that a liberal, anarchic, and hedonistic society such as the Culture can ever be fit for war. Not only do its adversaries mistake its lavish lifestyle for a sign of decadence and weakness, some of its citizens are also susceptible to such a flawed reasoning. In Consider Phlebas, a young boy lectures his fellow citizen Fal about the authoritarian virtues of the enemy: "I'm not so sure, he said, rubbing his chin. 'I'm not sure we have the will'. 'The will?' Fal said. 'Yes. The desire to fight. I think the Idirans are natural fighters. We aren't. I mean, look at us ... ' He smiled, as though he was much older and thought himself much wiser than she, and he turned his head and waved his hand lazily towards the island, where the boats lay tilted against the sand" (274).

Banks wants to make the point that authoritarianism is not intrinsically superior to liberalism, even in military matters, although initially it might prove difficult to mobilize an otherwise peaceful society into a full-scale war. After initial setbacks and withdrawals, the Culture is bound to win the war against the Idirans, thanks to the military might of their fully autonomous ships. For Banks, this victory is not just the result of technological superiority, but a triumph of the liberal order as such. The Culture was able to realize the technological potential of its ships to the fullest only by including machines as citizens and granting them full freedom and a sense of purpose. It is not hard to find parallels in human history: certainly, egalitarian societies and democratic governments have not been less successful at war than their illiberal counterparts.

Nevertheless, the Culture had to pay a price for its victory. Those who refused to participate in the war, machines and humanoids alike, formed the pacifist faction which left the Culture altogether. Confronted with the suffering caused by the war, millions of Culture citizens protested by putting themselves in digital hibernation, "only to be revived once the Culture could statistically 'prove' the war had been morally justified" (465), which happens hundreds of years later, when the suffering that the war supposedly prevented is considered to outweigh the suffering caused by it. Nevertheless, there is an insurmountable gap between the public meaning of the war and personal meanings, especially for its veterans. Balveda in Consider Phlebas (1987), a veteran of the war suffering from a trauma that she refuses to treat medically, is one of those revived but chooses to auto-euthanize several months later. The personal experience of war not only affects humanoids but also the sentient machines of the Culture. In Look to Windward (2000), the traumatized mind of a former warship that now runs a Culture orbital threatened by a terrorist attack voluntarily self-destructs. For Banks, suicide is an exit option that a truly liberal society needs to respect. 


\section{Diabolic Politics and the Problem of Liberal Interventionism}

The cultural structure of the Culture is characterized by a "religious" fervor to promote their own liberal values, occasionally through acts of warfare like the Idiran-Culture war in Consider Phlebas (1987), but mostly in the form of covert action which is, in one way or another, part of the plot of most Culture novels. It is a telling feature of the Culture that its society exhibits higher degrees of institutionalization in the boundary zones with other societies; it is as if contact with other societies confronts its liberal utopia with illiberal necessities of authority, elitism, and confidentiality. The necessity to interact with other civilizations led to the formation of the Contact section, a loose institutional network which serves as the diplomatic service and, if necessary, as the military arm of the Culture. Since its inception, it has spawned several independent subsections, most notoriously Special Circumstances (SC), Culture's "euphemism for military intelligence" (238). While only a minuscule part of the Culture, SC plays an important role in most Culture novels, and is frequently used by Banks to reflect upon the dilemmas of liberal intervention, and what I call, following Max Weber, the "diabolic" nature of politics.

In his "Politics as Vocation" (1949), based on a lecture delivered to the liberal Free Student Union in Munich on the 28th of January, 1919, Weber calls for an ethic of responsibility (Verantwortungsethik) within the limits of realpolitik: "Also the early Christians knew full well the world is governed by demons and that he who lets himself in for politics, that is, for power and force as means, contracts with diabolical powers and for his action it is not true that good can follow only from good and evil only from evil, but that often the opposite is true. Anyone who fails to see this is, indeed, a political infant" (123).

Weber rejects any "ethic of ultimate ends" (Gesinnungsethik), not only because it disregards the consequences of action but also because it is ultimately non-sustainable in the real world. The political experiment of "radical pacifist sects" in North America which "renounced violence towards the outside" took, according to Weber, "a tragic course, inasmuch as with the outbreak of the War of Independence the Quakers could not stand up arms-in-hand for their ideals, which were those of the war" (1949: 124). Radical pacifism is ultimately self-defeating; it can only persist if pacifist communities are protected by a larger, more belligerent society. The same can be said about liberalism, which may not be spread or even sustained without occasionally violating liberal principles themselves. Rather surprisingly, the utopia of the Culture ultimately serves to highlight the diabolic realpolitik of liberalism.

The Contact section in general and SC in particular serve as institutional buffer-zones of moral and political ambiguity, which absorb the diabolic qualities of liberal politics so that the rest of the Culture can enjoy its clear conscience. As "the elite of the elite, in a society which abhor[s] elitism" (1987: 30), SC agents have an ambivalent reputation in the Culture, being dismissed as immoral but also envied for their exciting lives. In the Culture, SC represents the ambivalence of the liberal sacred, and their transgressive acts can be regarded as polluted and sacred at the same time (cf. Kurakin, 2015). While the Culture in general and SC in particular think of themselves as being on the right side, 
they readily admit that there is no such thing as moral certainty. As the SC agent Zma in Use of Weapons confesses, “. . . in Special Circumstances we deal in the moral equivalent of black holes, where the normal laws - the rules of right and wrong that people imagine apply everywhere else in the universe-break down; beyond those metaphysical event horizons, there exist . . . special circumstances" (Banks, 1990: 284f.).

While this sounds like "a good excuse for bad behavior", the agent adds: "at least we need an excuse; think how many people need none at all” (Ibid.: 285). What allows Banks to pose the liberal dilemma in ideal-typical purity is precisely the fact that the Culture is conceptualized as a post-scarcity society, which does not have any kind of material interest in the rest of the galaxy. No mundane interests interfere with the politics of the sacred and the profane, although the chaotic nature of reality twists and warps even the most ideal intentions to unanticipated ends. According to Banks, the liberal order, even in its most utopian expression, is necessarily contradictory, or even incomplete. Normative orders such as morality contain within themselves a Gödelian paradox, which lies also at the core of the liberal dilemma regarding the use of torture at the beginning of the 21st century (Binder, 2014, 2016). The exclusive inclusion of SC is one way to deal with this paradox, keeping the subsection at the margins of the Culture where they cannot contaminate the clear conscience of most Culture citizens, who readily distance themselves from the deeds of SC agents in case one of their interventions fails.

In the Culture's liberal utopia, the conscience of the individual reigns supreme. Unable to avoid the Gödelian paradox of morality and the decisionism it entails, the Culture delegates moral decisions to individuals as the ultimate authority on these matters. Regardless of the Culture's efforts to justify wars and interventions, its citizens always have the option to dissent, join a separate faction, or leave the Culture entirely. Individuals also have the freedom to act as they seem fit, which includes the powerful minds of the Culture. No wonder that some of the sinister plots in the Culture novels are attributed to a conspiracy of "hawkish" minds which aim to shake things up - for the best of the Culture, of course. In his Culture novels, Banks tends to highlight ambivalent moral decisions and liberal interventions with catastrophic consequences. This does not mean, however, that he gave up on the Culture as a liberal utopia, nor does it mean that he opposes liberal interventions in principle. ${ }^{10}$ It just means that Banks is no "political infant" (Weber, 1949: 123), and neither is the Culture. It is in this sense that the Culture series can be read as a political Bildungsroman.

The Culture is not only a liberal society, but it is also a society that has demonstrated a capacity for learning: first, in the war against the Idirans and its fallout, and later, from its less-successful liberal interventions. In the last novel of the series, Hydrogen Sonata (2012), the Culture adopts a more cautious interventionist approach, which finds its symbolic expression in the piece of fictional music that gave the book its title. Originally written for a music instrument yet to be invented, the Hydrogen Sonata is incredibly difficult

10. Banks and his wife allegedly ripped up their passports and send the pieces to Tony Blair out of protest against the British involvement in the Iraq war-a gesture that made it difficult for Banks to promote his novels abroad. 
to play and sounds rather unpleasant. Nevertheless, one of the protagonists of the novel commits herself to learning the instrument and the sonata, growing two additional limbs to be able to do so. Her struggle to master the tune not only depicts what near-immortal beings in a post-scarcity society might spend their time on, but also serves, according to Ivaylo R. Schmilev, as a metaphor for the Culture's engagement with the real:

\begin{abstract}
The titular Hydrogen Sonata she slowly and painstakingly learns to play is a symbol of attachment to a limiting, painful, sometimes even torturing reality which nevertheless brings rewards. ... The Hydrogen Sonata is then-just like every one of Banks' sf novels-not a tragedy, but a tribute to the unbroken engagement with the limitations of reality and to the triumphs of those who, under the direst of circumstances, persevere in this engagement (2016: 67f.).
\end{abstract}

Banks makes this point repeatedly in his Culture novels, which is rather ironic considering the fact that they belong to the genre of science fiction and to the genre of literary utopias, which are both genres under the-not entirely unfounded-hermeneutic suspicion of serving primarily the function of "wish-fulfillment". Paradoxically, the liberal utopia of the Culture is used by Banks to reflect on liberal realpolitik, its aspirations and limitations.

\title{
Conclusion
}

Banks' Culture series offers a liberal myth of a distant future that nonetheless strikes close to home. It is a literary myth that brings "the unconscious cultural structures that regulate society into the light of the mind" (Alexander, 2003: 3f.), and that uses the artistic imagination of a writer to dissect the foundations and explore the implications of the liberal order, thus addressing the contemporary crisis as well as the eternal dilemmas of liberalism. We may not live in a liberal utopia, but the dilemmas that the Culture faces are our own. Even Banks' reflections about living a meaningful life in a post-scarcity society are not so far away as it sometimes seems, at least for members of the affluent middle and upper classes of our societies.

Some of his concerns might even become more relevant in the near future with the progress of artificial intelligence and emerging debates about Universal Basic Income (UBI). It is striking that the discourse about UBI shows the same cleavage between liberal and authoritarian thinking which we find in Banks' novels (and Orwell's review of Mein Kampf). Leaving the technical questions concerning the economic feasibility of UBI aside, here we see another theater of a "culture war" in which conservatives (though some call themselves liberals or even socialists) claim that wage labor, which necessarily entails suffering, domination, and exploitation, is indispensable for a meaningful life-not for all people, of course, and the critics of UBI usually exclude themselves, but surely for the masses. This eerily mirrors antique discourses on slavery, according to which some humans are simply unfit to cope with the freedom that is the prerequisite of being a citizen. 
Arguments like this_-and the doublethink accompanying them-show up frequently among the representatives of authoritarian societies in the Culture novels: the Azad empire enforces strict hierarchies and norms for the good of the "common people", while its ruling elite enjoys transgressing them (Banks, 1989); Paluvean conservatives instill the fear of artificial hells, which exist in (virtual) reality, in their people to keep them in line (2010). Fear, pain, and sacrifice may be necessary to sustain an authoritarian order, but they are an anathema to the liberal order. As a self-conscious liberal, Banks rejects such arguments and the dark anthropology they entail. Instead, liberals need to put faith in their fellow citizens and the future.

Liberals and authoritarians indeed have different anthropologies. While both are centered on meaning, they differ in their structures of meaning. Liberals engage in a "discourse of liberty" while authoritarians favor a "discourse of repression" (cf. Alexander, 2006). Authoritarians stress the importance of domination, suffering, and sacrifice, while liberals promote freedom. Liberals do not deny that suffering and sacrifice are important sources of meaning but consider them only permissible if they are the result of an exercise of freedom. Nevertheless, as Banks demonstrates in his Culture series, the reality of politics and morality does not always match these neat binaries. As liberals, we have to accept the fact that politics is diabolic. Alexander argues: "We need narratives if we are to make progress and experience tragedy" (2003: 4); Banks' Culture novels suggest that progress and tragedy are inextricably linked.

\section{References}

Alexander J. C. (2003) The Meanings of Social Life: A Cultural Sociology, Oxford: Oxford University Press.

Alexander J. C. (2006) The Civil Sphere, Oxford: Oxford University Press.

Alexander J. C. (2019) What Makes a Social Crisis? The Societalization of Social Problems, Cambridge: Polity.

Banks I. M. (1987) Consider Phlebas, London: Macmillian.

Banks I. M. (1989) The Player of Games, London: Macmillan.

Banks I. M. (1994) A Few Notes on the Culture. Available at: http://www.vavatch.co.uk/ books/banks/cultnote.htm (accessed 7 September 2020).

Banks I. M. (200o) Look to Windward, London: Orbit.

Banks I. M. (2010) Surface Detail, London: Orbit.

Banks I. M. (2010) The Hydrogen Sonata, London: Orbit.

Binder W. (2014) Moral, Ambivalenz und Narration. Ungefähres. Mythos, Moral, Gewalt (eds. B. Giesen, W. Binder, M. Gerster, K.-C. Meyer), Weilerswist: Velbrück, pp. 12O139.

Binder W. (2016) Shifting Imaginaries in the War on Terror: The Rise and Fall of the Ticking Bomb Torturer. Social Imaginaries, vol. 2, no 1, 119-150.

Branscobe M., Banks I. M. (2007) What's in an M (or) What a Difference an M Makes: Interview with Iain M. Banks, September 28, 2007. Available at: https://web.archive. 
org/web/20070928164721/http://www.sandm.co.uk/mary/sfjournm/Iain_Banks/ iain_banks.html (accessed 7 September 2020).

Colebrook M., Cox K. (eds.) (2013) The Transgressive Iain Banks: Essays on a Writer Beyond Borders, London: McFarland.

Duggan R.t (2007) Iain M. Banks, Postmodernism and the Gulf War. Extrapolation, vol. 48, no 3, pp. 558-577.

Durkheim É. (1969/1898) Individualism and the Intellectuals. Political Studies, vol. 17, pp. 19-30.

Durkheim É. (1995/1912) The Elementary Forms of the Religious Life, New York: Free Press. Fukuyama F. (1992) The End of History and the Last Man, New York: Free Press.

Future of Life Institute (2020) An Open Letter: Research Priorities for Robust and Beneficial Artificial Intelligence. Available at: https://futureoflife.org/ai-open-letter (accessed 7 September 2020).

Jackson P. Th. (2013) Outside of Context: Iain M. Banks, 1954-2013. Duck of Minerva, June 10, 2013. Available at: https://duckofminerva.com/2013/o6/outside-of-contextiain-m-banks-1954-2013.html (accessed 7 September 2020).

Jacobs A. (2009) The Ambiguous Utopia of Iain M. Banks. The New Atlantis: A Journal of Technology and Society, Summer, pp. 45-58.

Jones G. (2001) Science Fiction. The New York Times, October 7, 2001. Available at: https://www.nytimes.com/2001/10/07/books/science-fiction.html (accessed 6 September 2020).

Kelly S. (2018) Does Elon Musk Really Understand Iain M Banks's "Utopian Anarchist" Culture? The Guardian, June 19, 2018. Available at: https://www.theguardian.com/ books/booksblog/2018/jun/19/elon-musk-iain-banks-culture-novels (accessed 6 September 2020).

Kerslake P. (2007) Science Fiction and Empire, Liverpool: Liverpool University Press.

Kincaid P. (2018) Iain M. Banks, Urbana: University of Illinois Press.

Krastev I., Holmes S. (2020) The Light That Failed: Why the West is Losing the Fight for Democracy, New York: Pegasus Books.

Kurakin D. (2015) Reassembling the Ambiguity of the Sacred: A Neglected Inconsistency in Readings of Durkheim. Journal of Classical Sociology, vol. 15, no 4, pp. 377-395.

Latour B. (2017) Facing Gaia: Eight Lectures on the New Climatic Regime, Cambridge: Polity.

Luhmann N. (2008/1993) Are There Still Indispensable Norms in Our Society? Soziale Systeme, vol. 14, no 1, pp. 18-37.

MacLeod K. (2003) Phlebas Reconsidered. The True Knowledge of Ken MacLeod (eds. A. M. Butler, F. Mendlesohn), Reading: Foundation Studies in Science Fiction, pp. 1-3. Martingale M. (2013) Gothic Dimensions, Marston Gate: Quetzalcoatal.

Mendlesohn F. (2005) The Dialectic of Decadence and Utopia in Iain M. Banks' Culture Novels. Foundation, vol. 93, pp. 116-124.

Nietzsche F. (2006) Thus Spoke Zarathustra: A Book for All and None, Cambridge: Cambridge University Press. 
Nussbaum A. (2018) A Political History of the Future: Iain M. Banks. Available at: https:// www.lawyersgunsmoneyblog.com/2018/o3/political-history-future-iain-m-banks (accessed 7 September 2020).

Orwell G. (1940) Review of Mein Kampf by Adolf Hitler. The New English Weekly, March 21.

Orwell G. (1949) Nineteen Eighty-Four, London: Secker \& Warburg.

Prucher J. (ed.) (2007) Brave New Words: The Oxford Dictionary of Science Fiction, Oxford: Oxford University Press.

Rawls J. (1999) A Theory of Justice, Cambridge: Harvard University Press.

Schmilev I. (2016) From a Galactic War to a Hydrogen Sonata: Warfare and Ethics in the Culture Novels of Iain M. Banks. Foundation, vol. 124/45, no 2, pp. 57-69.

Schmitt C. (1997/1942) Land and Sea, Washington: Plutarch Press.

Schmitt C. (2003/1950) The Nomos of the Earth in the International Law of the Jus Publicum Europaeum, New York: Telos.

Sloterdjik P. (2015) In the World Interior of Capital, Cambridge: Polity.

Stubby the Rocket (2015) Elon Musk Names SpaceX Drone Ships in Honor of Iain M. Banks. Available at: https://www.tor.com/2015/01/23/elon-musk-iain-m-banks-justread-the-instructions/ (accessed 1 September 2020).

Suleiman S. R. (1983) Authoritarian Fictions: The Ideological Novel as a Literary Genre, New York: Columbia University Press.

The Times (2008) The 50 Greatest British Writers since 1945. The Times, January 5, 2008. Available at: https://www.thetimes.co.uk/article/the-50-greatest-british-writerssince-1945-ws3g69xrf9o (accessed 30 October 2020).

Tognato C., Jaworsky N., Alexander J. C. (eds.) (2020) The Courage for Civil Repair: Narrating the Righteous in International Migration, Cham: Palgrave Macmillan.

Tolkien J. R. R. (1995/1965) Foreword to the Second Edition. The Lord of the Rings, London: HarperCollins, pp. xv-xviii.

Weber M. (1949) Politics as a Vocation. From Max Weber: Sociological Essays (eds. H. H. Gerth, C. W. Mills), Oxford: Oxford University Press, pp. 77-128. 


\section{Либеральный порядок за пределами Земли? Гражданская сфера, «Культура» и будущее либерализма}

\section{Вернер Биндер}

$\mathrm{PhD}$, доцент, департамент социологии, факультет социальных наук, Масариков университет Адрес: Joštova 10, 602 oo Brno, Czech Republic

E-mail: werner.binder@muni.cz

Начиная с либеральной проблемы смысла Джорджа Оруэлла, эта статья исследует либерализм как культурную структуру и миф, опираясь на теорию гражданской сферы Джеффри К. Александера и научно-фантастические романы Иэна М. Бэнкса. Вслед за Александером утверждается, что либеральные общества строятся вокруг сакрального ядра, описываемого культурными структурами гражданской сферы. Они же являются структурами смысла и чувства. Гражданские дискурсы и движения в либеральных (и не очень либеральных) обществах мобилизуют мощные символы сакрального и профанного и, таким образом, способны внушать почти религиозную преданность. Далее в статье исследуется смысловая структура, культурные противоречия и возможное будущее либерального порядка на основе обсуждения серии «Культура» Иэна Бэнкса. Действие этих романов происходит в границах «Культуры» - галактической цивилизации и либеральной утопии. Именно в этой утопической среде Бэнкс исследует внутренние дилеммы либерализма, например, между пацифизмом и интервенционизмом, обращаясь и к актуальным вопросам, таким как либеральная проблема смысла, очарование авторитаризмом или социальный статус искусственного интеллекта. С помощью литературного воображения писателифантасты конструируют «миф будущего» (Бэнкс), который зачастую соответствует мифам современности, но также - как в случае Бэнкса — переосмысляет их, их противоречия и последствия. Наконец, воображаемые вариации социального порядка в научной фантастике могут быть ценным источником для воображения социологов, рассматривающих саму возможность социального порядка.

Ключевые слова: социология культуры, гражданская сфера, либерализм, авторитаризм, научная фантастика, «культура», Джеффри К. Александер, Иэн М. Бэнкс 